\title{
Complicated colorectal cancer in nonagenarian patients: is it better not to perform anastomosis in emergency?
}

\author{
Belinda De Simone, M.D., ${ }^{1}$ Federico Coccolini, M.D., ${ }^{2}$ Luca Ansaloni, Prof., ${ }^{2}$ Antonio Tarasconi, M.D., ${ }^{3}$ \\ Gianluca Baiocchi, M.D., ${ }^{3}$ Nereo Vettoretto, M.D., ${ }^{4}$ Peggy Joly, M.D., ${ }^{5}$ Marianne Ferron, M.D., ${ }^{5}$ \\ Alessandro Pozzo, M.D., ${ }^{5}$ Lionel Charre, M.D., ${ }^{5}$ Salomone Di Saverio, M.D., ${ }^{6}$ Josephine Andrea Napoli, M.D., ${ }^{7}$ \\ Ferdinando Agresta, M.D., ${ }^{8}$ Massimo Sartelli, M.D., ${ }^{9}$ Fausto Catena, Prof. ${ }^{1}$
}

\author{
1'Department of Emergency Surgery, University Hospital of Parma, Parma-Italy \\ ${ }^{2}$ Emergency and General Surgery Department, Papa Giovanni XXIII Hospital, Bergamo-Italy \\ ${ }^{3}$ Department of General and Emergency Surgery, Ospedali Civili, Brescia-Italy \\ ${ }^{4}$ Department of General and Emergency Surgery, Montichiari Hospital, Brescia-Italy \\ ${ }^{5}$ Department of General and Emergency Surgery, Renè Dubos Hospital, Pontoise-France \\ ${ }^{6}$ Emergency and General Surgery Department, Maggiore Hospital, Bologna-Italy \\ ${ }^{7}$ Department of Surgical Sciences, University of Hawaii-United States of America \\ ${ }^{8}$ Department of General Surgery, Adria Hospital, Adria-Italy \\ ${ }^{9}$ Department of General Surgery, Macerata Hospital, Macerata-Italy
}

\section{ABSTRACT}

BACKGROUND: Colorectal cancer (CRC) is predominantly a disease of elderly people. Cancer in nonagenarian patients presents an ethical dilemma for surgeons and oncologists, and management of this group of patients in emergency for complicated CRC is debated. Presently described is retrospective study reporting experience of 6 departments of emergency surgery with management of nonagenarian patients sent to emergency surgery for CRC complications.

METHODS: Data concerning patients aged over 90 years hospitalized from January 2011 to June 2015 in 6 departments of emergency surgery for complicated CRC were retrospectively analyzed. Data were collected in a dedicated database. Statistical analysis was conducted using IBM software SPSS 22 (IBM Corp., Armonk, NY, USA); statistical significance was set at $\mathrm{p}=0.05$.

RESULTS: In the period of study, 19 patients aged over 90 underwent surgery in emergency department for complicated CRC. Of the total, $52.63 \%$ were female, with sex ratio F:M of I.II:I. Mean age was 92.52 years (range: $90-97$ years; SD I.49). Preoperative assessment of surgical risk was made using American Society of Anesthesiologists (ASA) score. There was no statistically significant difference in terms of in-hospital mortality between patients with ASA score $\leq 3$ and patients with an ASA score $>3$. Primary anastomosis was performed in 6 of 19 patients (31.57\%), all of whom had right-side colon cancer. Diverting stoma was created for 12 of 19 patients $(63.15 \%)$. There was a statistically significant difference in incidence of postoperative complications between patients with right-side colon cancer and patients with left-side colon cancer $(p=0.0498)$. Mean length of hospital stay was I2.78 days (range: 2-3I days; SD 6.31). In-hospital mortality rate was $21.05 \%(n=4)$. At follow up, overall survival was $47.36 \%(n=9)$.

CONCLUSION: Elective surgery is the best way to manage CRC in all patients affected. Emergency surgery for CRC complications in patients over 90 is feasible with careful preoperative selection and evaluation of the patient. One-stage surgery is the best choice, in selected patients. Two- and three-stage surgery is indicated in case of peritonitis, for frail patients, for hemodynamically unstable patients. If there is high risk of anastomotic leakage, decompressive stoma is suggested as bridge to elective surgery, and in advanced neoplastic disease, as palliative procedure. In emergency setting, diverting stoma is a good surgical option in nonagenarian patients to decrease surgical risk, morbidity, and mortality; however, clinical randomized controlled trials are necessary to confirm this.

Keywords: Colorectal cancer; decompressive stoma; emergency surgery; large bowel obstruction; oncogeriatric patient; primary anastomosis.

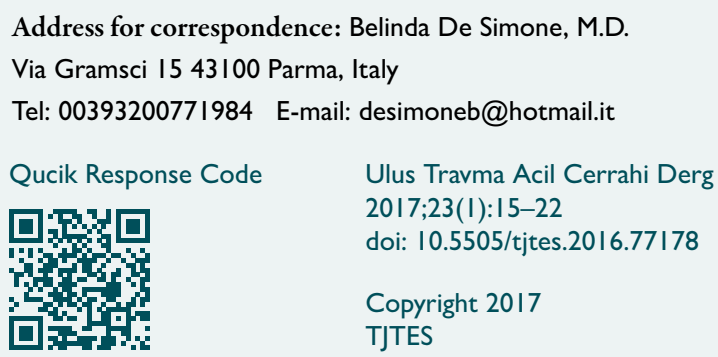

\section{INTRODUCTION}

Colorectal cancer (CRC) is predominantly a disease of elderly people; over $70 \%$ of cases occur in patients aged over 65 years, with mean age at diagnosis of 72 years. ${ }^{[1-3]}$

A natural consequence of the improvement of living conditions and achievement of high standards of care is aging world population with growing number of those over 90 years of age. 
In Italy, population aged 85 and older will increase from $2.8 \%$ in 2011 to $7.8 \%$ in 2050 . Average life expectancy is projected to be 85.3 years for males and 90.5 years for females (Italian National Institute of Statistics data).

This highly significant change in age demographics and within society has an important impact on healthcare, and especially cancer care. Treating cancer in people aged over 90 presents an ethical dilemma for surgeons and oncologists.

In clinical practice, management of this group of patients is frequently suboptimal and there is an increasing number of nonagenarian CRC patients requiring emergency surgical treatment due to serious complications of advanced neoplastic colic disease.

Emergency abdominal procedures are generally associated with increased morbidity and mortality rates, particularly for frail elderly patients. Emergency surgeon often has crucial role of selecting patients for surgery, and balancing benefits and high surgical risk. Another important issue to consider is high cost of postoperative care for this group of patients, which frequently requires rehabilitation and longer recovery, even after minor surgery.

In the recent literature there is still a lack of data concerning abdominal surgery in emergency conditions for nonagenarians; no randomized controlled trials look exclusively at elderly patients undergoing emergency surgery for CRC and no evidence-based clinical guidelines are available.

The aim of the present study was to report the experience of 6 departments of emergency surgery in the management of nonagenarian patients sent to emergency surgery for CRC complications and to analyze the outcomes of surgery.

\section{MATERIALS AND METHODS}

Data concerning patients aged over 90 years who were hospitalized between January $201 \mathrm{I}$ and June 2015 in 6 emergency surgery departments in Italy and France (Parma, Bergamo, Adria, Brescia, and Bologna, Italy and Pontoise, France) and underwent emergency abdominal surgery for complicated CRC, presenting with colic obstruction or perforation at admission were retrospectively analyzed.

Data used for the study were demographic characteristics, preoperative comorbidities, operative and postoperative information. These data were collected in a dedicated database. Perioperative individual surgical risk was assessed using American Anesthesiology Association (ASA) score.

Follow-up to assess overall survival was made by phone call.

Statistical analysis was performed using IBM software SPSS 22 (IBM Corp., Armonk, NY, USA), and statistical significance was set at $\mathrm{p}=0.05$.

\section{RESULTS}

Between January 20II and June 2015, 19 patients over age 90 underwent emergency abdominal surgery for complicated CRC in 6 emergency surgery departments included in the study.

Of the total, $52.63 \%$ of these patients were female, with a sex ratio F:M of I.I I:I. Mean age was 92.52 years (range: $90-97$ years; SD: I.49).

For all of these patients, obstruction and peritonitis were primary manifestation of neoplastic disease.

At admission, 14 patients $(73.68 \%)$ presented with intestinal obstruction, and 5 patients $(26.31 \%)$ presented with peritonitis and colic perforation.

Majority of patients had co-existing diseases: 16 patients (84.21\%) had arterial hypertension ; chronic obstructive pulmonary disease (COPD) was present in 5 patients $(26.31 \%$ ); diabetes, without distinguishing between type $\mathrm{I}$ or 2 , was seen in 4 patients (21\%); chronic renal insufficiency, defined by serum creatinine $\geq 2 \mathrm{mg} / \mathrm{dL}$ was observed in 3 patients (15.78\%); and chronic cardiovascular disease, chronic heart failure, or arrhythmia was present in 13 patients $(84.21 \%)$, as summarized in Table I.

Preoperative assessment of surgical risk was made using ASA score: $57.89 \%$ of patients $(n=I I)$ had an ASA score of 3, $31.57 \%$ of patients $(n=6)$ had ASA score of 4 and $10.52 \%$ of patients $(n=2)$ were classified with ASA score of 2 .

Considering $p<0.05$, there was no statistically significant difference in in-hospital mortality between the group of patients with ASA score of $\leq 3$ and patients with ASA score of $>3$.

Mean length of time between admission and surgical procedure was 53.81 hours (range: 2-264 hours; SD 65.38).

General anesthesia was used for all surgeries. Surgical exploration was performed by laparotomy in 18 patients $(94.73 \%)$, with a mean surgical time of 94.44 minutes (range: 45-180 minutes; SD 35. 10). One exploratory laparoscopy associated with diverting ileostomy was performed for peritoneal carcinomatosis.

Tumor was localized in the right colon in 8 patients $(42.10 \%)$, the left colon/sigmoid colon in 8 patients $(42.10 \%)$, and the transverse colon in 2 patients (10.52\%); peritoneal carcinomatosis was found in I patient during surgery.

Primary and secondary surgical procedures performed are summarized in Table 2.

After colic resection, primary anastomosis was performed in 
Table I. Co-existing diseases at the admission

\begin{tabular}{lcr}
\hline Co-existing diseases & Number of patients & $\%$ \\
\hline Arterial hypertension & $16 / 19$ & 84.21 \\
Chronic cardiovascular diseases & $13 / 19$ & 68.42 \\
Chronic obstructive pulmonary disease & $5 / 19$ & 26.31 \\
Dementia & $3 / 19$ & 15.78 \\
Diabetes & $4 / 19$ & 21.05 \\
Chronic renal insufficency & $3 / 19$ & 15.78 \\
\hline
\end{tabular}

Table 2. Surgical procedures performed

\begin{tabular}{lcr}
\hline Surgical procedures & Number of patients & $\%$ \\
\hline Right hemicolectomy with anastomosis & $6 / 19$ & 31.57 \\
Left hemicolectomy with loop ileostomy & $1 / 19$ & 5.26 \\
Sigmoidectomy with loop ileostomy & $1 / 19$ & 5.26 \\
Right hemicolectomy enlarged to the transverse colon with ileocolostomy & $1 / 19$ & 5.26 \\
Subtotal colectomy with double stoma & $1 / 19$ & 5.26 \\
Hartmann's procedure & $2 / 19$ & 10.52 \\
Decompressive left colostomy & $2 / 19$ & 10.52 \\
Decompressive caecostomy & $2 / 19$ & 10.52 \\
End ileostomy & $2 / 19$ & 10.52 \\
Exploratory laparoscopy with diverting ileostomy & $1 / 19$ & 5.26 \\
\hline
\end{tabular}

6 patients (31.57\%), and temporary or permanent diverting stoma (colostomy, ileostomy, ileocolostomy) was created in 12 patients $(63.15 \%)$.

Specifically, 6 right hemicolectomies with contemporary anastomosis, I left hemicolectomy with temporary diverting ileostomy, I sigmoidectomy with temporary loop ileostomy, I right hemicolectomy enlarged to the transverse colon with ileocolostomy, I subtotal colectomy with double stoma, 2 Hartmann's procedures, 2 decompressive cecostomies, 2 decompressive left colostomies, 2 end ileostomies, and I exploratory laparoscopy were performed (Table 2).

Total of 12 patients (63.15\%) had no postoperative complications, while $21.05 \%$ of patients $(n=4)$ had complications related to surgery: 3 surgical site infections and I anastomotic dehiscence. In addition, 3 patients (15.78\%) had medical complications: I instance of heart failure, 2 cases of pneumopathy. Using the Clavien-Dindo classification system of surgical complications, 4 of the 7 patients (57.14\%) were classified grade 2 , and remaining 3 patients were classified grade 5 . One patient died of unknown causes.

Given that $p<0.05$, incidence of postoperative complications was significantly higher in group of patients with right colon cancer $(p=0.0498)$, compared with patients with left colon cancer.

No statistically significant difference was found in overall survival between patients who underwent colonic resection with primary anastomosis and patients with diverting stoma $(p=0.64)$.

There was no statistically significant difference in in-hospital mortality rate between patients operated on in first 24 hours after admission and patients who underwent surgery more than 24 hours after admission $(p=0.60)$.

Mean length of hospital stay was 12.78 days (range: 2-3I days; SD 6.31).

In-hospital mortality was $21.05 \%(n=4)$.

Five patients $(33.3 \%)$ were discharged to home and remaining 10 patients $(66.66 \%)$ were transferred to long-term care facilities.

Mean time of follow up was 6.31 months (range: 0-26 months; SD 7.7I). At follow-up, overall survival was $47.36 \%$ (9 of 19 patients). 


\section{DISCUSSION}

The growing population of the elderly is leading to increase in number of patients aged over 90 who need surgical treatment in emergency setting for complicated CRC.

Clinical features such as bowel obstruction and abdominal pain may be primary manifestations of neoplastic colic disease, or they may represent late complications in patients judged unfit for surgery or who refused surgical and medical treatment.

Frequently, symptoms at admission are aspecific: severe asthenia, anorexia, dyspnea, nausea, vomiting, chronic abdominal pain without defense on the clinical examination, and rarely, fever.

Difficulty in obtaining an accurate history can delay surgical decision-making, thereby increasing mortality.

Abdominal computed tomography (CT) has been demonstrated to be the best radiological diagnostic test for elderly patients with acute abdominal pain. Reginelli et al. retrospectively analyzed data from 126 patients aged 65 years and older who presented at emergency department with acute abdominal pain in order to assess the diagnostic performance of abdominal CT. He reported that in the care of elderly patients, $\mathrm{CT}$ is accurate for diagnosing cause of acute abdominal pain, particularly when it is of gastrointestinal surgical origin. ${ }^{[3]}$

Compared with younger patients admitted to acute care surgery service, patients over 80 years of age have higher risk of complications and increased morbidity and mortality rates, ${ }^{[1-4]}$ although improvements in preoperative care, surgical techniques, and advancements in anesthesiology and intensive therapies have made surgery feasible for the majority of elderly patients.

There is still a lack of studies evaluating early and late outcomes of emergency abdominal surgery in the cohort of patients aged over 90 with CRC, and there is no consensus about optimal surgical management for elderly people admitted to the emergency department with diagnosis of complicated CRC.

The emergency surgeon has the crucial role of selecting patients who may benefit from surgical treatment in an emergency, weighing high surgical risk due to comorbidities, polypharmacy, advanced age, and surgical outcomes.

In surgical decision-making, they have to evaluate whether to administer the treatment with palliative or curative intent, and finally, to clearly communicate the decision to relatives. As result of these issues, they require a model or a scoring system to use in preoperative evaluation to predict postoperative mortality in patients older than 90 years.
Smothers, in a controlled case study of 184 patients who underwent primary surgery in elective and emergency settings for colon cancer, concluded that emergency surgery has strong negative influence on immediate surgical morbidity and mortality, without distinguishing patients by age. ${ }^{[5]}$ This is most likely related to degree of severity of the patient at admission. Moreover, we have to know that in very elderly patients, there is decline in physiological reserves, which makes the patient vulnerable to any stressful event. ${ }^{[6,7]}$

However chronological age cannot be the only selection factor to consider in surgical decision-making; in fact, a considerable number of elderly patients will continue to live with good function and excellent quality of life after emergency surgery. ${ }^{[6-9]}$

There is great variation in individual health status with increasing age: physiological/biological age is not often chronological age.

Many patients in our study had comorbidities, but none were predictive of postoperative complications or early mortality. The patient aged over 90 years is generally defined as "frail" to indicate weak or vulnerable status, sustained by co-existing chronic disease and poly-pharmacy; we have to understand that frailty is a physiological status that comes with aging.

In the literature, "frailty phenotype" is defined by presence of 5 criteria: unintentional weight loss, self-reported exhaustion, weakness (grip strength), slow walking speed and low physical activity. ${ }^{[6,7]}$

Many frailty screening tests are available to determine if elderly patients qualify for emergency abdominal surgery. ${ }^{[8,9]}$

Kenig, in a prospective study conducted with 184 patients aged $\geq 65$ years, reported that it is possible to perform safe and efficient screening for frailty in older candidates for emergency surgery, and that Vulnerable Elders Survey-13, which simply asks questions about independent living, was the best screening instrument with highest sensitivity and negative predictive value for both postoperative mortality and morbidity. ${ }^{[10]}$

Gomes et al. reported that Colorectal Physiologic and Operative Severity Score for the Enumeration of Mortality and morbidity (CR POSSUM) was the best predictor of surgical mortality and morbidity, that POSSUM and Portsmouth POSSUM scoring systems underestimated surgical mortality and morbidity, and that Colorectal Biochemical and Haematological Outcome Model overestimated surgical mortality. However, none of the scores in his retrospective study demonstrated sufficient discriminatory power to have clinical application value. Moreover, Gomes stated that in elderly patients, it is the patient's health status and not the type of surgery that is mainly responsible for the surgical outcome. ${ }^{\left[{ }^{\prime \prime}\right]}$ 
In emergency conditions, it is fundamental to have a predictive test that is easy and quick to administer in order to select patients for surgery, even in cases of altered cognitive status.

In our experience, individual preoperative risk in nonagenarian patients was assessed using ASA classification because it can be determined quickly on admission and it has been shown in the literature to be predictive of complications and mortality. Consistent with results of recent retrospective studies, ${ }^{[7,8,12]}$ in our cohort of patients, high ASA class was associated with high mortality following emergency surgery, but we found no statistically significant difference between patients with ASA score $\leq 3$ and patients with ASA score $>3$. This may be because very elderly patients with high ASA score, affected by severe disease, needed to be treated first in ICU, where they often die. Consequently, in our study we included patients who were already selected by ASA classification at admission.

In our experience, mean delay in surgery was 53.81 hours.

Some authors have reported that time between admission and surgery does not increase morbidity and mortality rates; ${ }^{[13]}$ others demonstrated that delay in performing emergency surgery in elderly patients leads to higher complication rates. ${ }^{[14]}$ We did not find a statistically significant difference in patients operated on within 24 hours in terms of early mortality rate. We have to consider that several patients needed to be monitored and clinically stabilized in department of internal medicine before surgery, and this may be a factor responsible for delay in surgery.

After making the decision to perform surgery, the primary objectives of the emergency surgeon are maintenance of independence, life expectancy, and quality of life of the elderly patient.

Surgical treatment of large bowel obstruction for cancer depends on location of colic obstruction, intraoperative findings, patient's general condition, patient's nutritional status, and the experience of the surgeon. ${ }^{[15-22]}$

Generally right hemicolectomy with primary anastomosis and eventually extended to the transverse colon is indicated for right-sided lesions or transverse colon-obstructing cancers.

In case of left-sided lesions, surgical treatment is still debated and includes:

-primary resection and anastomosis associated with on-table irrigation or manual decompression of the colon (one-stage procedure). It prevents the confection of a loop colostomy but presents risk of anastomotic leakage;

-Hartmann's procedure (two-stage surgery), which allows the treatment of both obstruction and cancer and prevents anas- tomotic leakage, but requires second operation to reverse the colostomy;

-three stage procedure (decompressive colostomy-colic resection-colostomy closure);

-subtotal or total colectomy with/without primary anastomosis, indicated in case of diastatic colon perforation or synchronous right colonic cancer; and -temporary or definitive loop colostomy/ileostomy, in case of important bowel dilatation proximal to obstruction, advanced neoplastic disease, or peritoneal carcinomatosis due to high risk of anastomotic leakage. ${ }^{[20-23]}$

In the literature, many studies have reported increasing number of surgical procedures involving creation of diverting sto$\mathrm{ma}$, and this seems to increase with age, ${ }^{[24]}$ probably with the aim of avoiding anastomotic dehiscence in frail nonagenarian patients. Several authors have reported that if the patient does not exhibit hypoalbuminemia, the surgeon may be able to perform an emergency operation with low risk of surgical mortality. ${ }^{[25]}$

Immediate colic resection with primary anastomosis is optimal in selected patients with low risk, either a typical resection with washout, or subtotal colectomy. Temporary defunctioning colostomy or ileostomy could be proposed for patients with intermediate anesthetic risk, and in high-risk cases with advanced obstruction, simultaneous colonic perforation, metastatic or locally advanced disease, Hartmann's procedure should be preferred as safer surgical procedure. ${ }^{[26]}$

The World Society of Emergency Surgeons, after a consensus conference on management of obstructing cancer of the left colon, stated that primary resection and anastomosis with manual decompression seems to be procedure of choice; loop colostomy and staged procedure should be adopted in extreme cases when neoadjuvant therapy could be expected. Hartmann's procedure should be performed in case of high risk of anastomotic dehiscence, and subtotal and total colectomy should be attempted in presence of cecal perforation or synchronous colonic neoplasms. ${ }^{[27]}$

In our experience, we performed 6 right hemicolectomies with primary anastomosis for right colon cancer. For left colon cancer, we performed 2 Hartmann's procedures, I sigmoidectomy with temporary diverting ileostomy, and 2 decompressive colostomies.

We had I dehiscent anastomosis in right hemicolectomy patient.

In our cohort of patients, incidence of postoperative complications was significantly higher in the group of patients with right colon cancer compared with patients with left colon cancer. This is probably a consequence of management 
of right and left obstructive cancers in emergency settings: surgeons feel safer performing primary anastomosis for right colon cancers than for left colon cancers. This means exposing the "non-selected," frail, geriatric patient to the risk of postoperative complications, increasing morbidity and mortality. ${ }^{[28,29]}$

In our experience, only anastomotic dehiscence was just after right hemicolectomy with primary anastomosis.

No significant statistical difference was found in mortality rate between patients with stoma and patients without stoma.

After surgery, length of stay is typically longer for patients aged over 90 years. Emergency surgical treatment of CRC is potential promoter of permanent disability in frail and vulnerable patients, and discharge is often to long-term care facilities. ${ }^{[29,30]}$

In the literature, longer hospitalization is often due to high incidence of Post Operative Delirium (POD). ${ }^{[3]}$ Ansaloni et al. affirmed that to minimize POD, associated risk factors of comorbidity, cognitive impairment, psychopathology, and abnormal glycemic control must be identified and treated. ${ }^{[32]}$

Delay in surgery is considered the most important risk factor in postoperative morbidity and mortality rates. In our experience, no statistically significant difference was found between patients who underwent surgery within 24 hours and those who were operated on later than 24 hours after admission.

In agreement with the literature, our population study of oncogeriatric patients revealed in-hospital mortality of $21.05 \%$ (4 of 19 patients), and at follow up, overall survival was $47.36 \%$ ( 9 of 19 patients were alive). Mean follow up time was 6.31 months. ${ }^{[33,34]}$

Several studies have found similar disease-specific survival rate for elderly and young colorectal cancer patients, ${ }^{[3,36]}$ but differences in overall survival, indicating that increased mortality in oncogeriatric patients was due to competing cause of death and not to CRC. Therefore, decreased survival in the elderly is mainly due to differences in early mortality. ${ }^{[36,37]}$

\section{Conclusion}

Elective surgery is the best way to manage CRC in all patients, but an increasing number of nonagenarians are admitted to emergency departments for complicated CRC.

Emergency surgery for complicated CRC in patients over 90 years old is feasible with careful selection and preoperative evaluation of the patient, which will maximize surgical outcomes.

In preoperative evaluation, emergency surgeon has to con- sider global health status using ASA score, nutritional status defined by albuminemia, and quality of life before hospitalization (degree of independence) of the geriatric patient needing surgery.

In emergency situations, nonagenarian patients with ASA score $1-3$, no hypoalbuminemia and high independence in daily activities have the same surgical risk as younger patients. One-stage surgery is the best choice, when possible, in selected patients. Two- and three-stage surgery is indicated in case of peritonitis, for frail patients, and for those who are hemodynamically unstable. For those with high risk of anastomotic leakage, decompressive ileostomy/colostomy is suggested as bridge to elective surgery, and in advanced neoplastic disease, as palliative procedure.

Risk of leakage or dehiscence of intestinal anastomosis is high both for right and left colic resection after emergency surgery in elderly patients.

We think that temporary colostomy or ileostomy is a good surgical option in nonagenarian patients, to decrease surgical risk, length of hospitalization, morbidity, and mortality, but clinical randomized controlled trials are necessary to confirm this.

In conclusion, a multidisciplinary approach to oncogeriatric patient and evidence-based clinical guidelines for management in emergency setting are essential in order to offer optimal, disability-free treatment and to not decrease life expectancy and overall survival.

\section{Conflict of interest: None declared.}

\section{REFERENCES}

1. Arenal JJ, Tinoco C, Labarga F, Martínez R, Gonzalo M. Colorectal cancer in nonagenarians. Colorectal Dis 2012;14:44-7.

2. Arenal JJ, Bengoechea-Beeby M. Mortality associated with emergency abdominal surgery in the elderly. Canadian journal of surgery 2003;2:111.

3. Reginelli A, Russo A, Pinto A, Stanzione F, Martiniello C, Cappabianca $\mathrm{S}$, et al. The role of computed tomography in the preoperative assessment of gastrointestinal causes of acute abdomen in elderly patients. Int J Surg 2014;12 Suppl 2:S181-6.

4. St-Louis E, Sudarshan M, Al-Habboubi M, El-Husseini Hassan M, Deckelbaum DL, Razek TS, et al.The outcomes of the elderly in acute care general surgery. European Journal of Trauma and Emergency Surgery 2015:1-7.

5. Smothers L, Hynan L, Fleming J, Turnage R, Simmang C, Anthony T. Emergency surgery for colon carcinoma. Diseases of the colon $\&$ rectum 2003;1:24-30.

6. Søreide K, Desserud KF. Emergency surgery in the elderly: the balance between function, frailty, fatality and futility.Scandinavian journal of trauma, resuscitation and emergency medicine 2015;1:10.

7. Fried LP, Tangen CM, Walston J, Newman AB, Hirsch C, Gottdiener $\mathrm{J}$, et al. Frailty in older adults evidence for a phenotype. The Journals of Gerontology Series A: Biological Sciences and Medical Sciences 2001;3:146-57. 
8. Hisada M, Katsumata K, Ishizaki T, Enomoto M, Matsudo T, Kasuya K, et al. Complete laparoscopic resection of the rectum using natural orifice specimen extraction. World J Gastroenterol 2014;20:16707-13.

9. Papamichael D, Audisio R, Horiot JC, Glimelius B, Sastre J, Mitry E, et al. Treatment of the elderly colorectal cancer patient: SIOG expert recommendations. Ann Oncol 2009;20:5-16.

10. Kenig J, Zychiewicz B, Olszewska U, Barczynski M, Nowak W. Six screening instruments for frailty in older patients qualified for emergency abdominal surgery. Arch Gerontol Geriatr 2015;61:437-42.

11. Gomes A, Rocha R, Marinho R, Sousa M, Pignatelli N, Carneiro C, et al. Colorectal surgical mortality and morbidity in elderly patients: comparison of POSSUM, P-POSSUM, CR-POSSUM, and CR-BHOM. Int J Colorectal Dis 2015;30:173-9.

12. Neuman HB, O'Connor ES, Weiss J, Loconte NK, Greenblatt DY, Greenberg CC, et al. Surgical treatment of colon cancer in patients aged 80 years and older : analysis of 31,574 patients in the SEER-Medicare database. Cancer 2013;119:639,47.

13. Vester-Andersen M, Lundstrøm LH, Buck DL, Møller MH. Association between surgical delay and survival in high-risk emergency abdominal surgery. A population-based Danish cohort study. Scand J Gastroenterol 2016;51:121-8.

14. Ong M, Guang TY, Yang TK. Impact of surgical delay on outcomes in elderly patients undergoing emergency surgery: A single center experience. World J Gastrointest Surg 2015;7:208-13.

15. Basili G, Lorenzetti L, Biondi G, Preziuso E, Angrisano C, Carnesecchi $\mathrm{P}$, et al. Colorectal cancer in the elderly. Is there a role for safe and curative surgery? ANZ J Surg 2008;78:466-70.

16. Ramesh HS, Pope D, Gennari R, Audisio RA. Optimising surgical management of elderly cancer patients."World journal of surgical oncology 2005;1:17.

17. Ugolini G, Ghignone F, Zattoni D, Veronese G, Montroni I. Personalized surgical management of colorectal cancer in elderly population. World journal of gastroenterology: WJG 2014;14:3762.

18. Lee YM, Law WL, Chu KW, Poon RT. Emergency surgery for obstructing colorectal cancers: a comparison between right-sided and left-sided lesions. J Am Coll Surg 2001;192:719-25.

19. Simmonds PD, Best L, George S, Baughan C, Buchanan R, Davis C, et al. Surgery for colorectal cancer in elderly patients: a systematic review. The Lancet 2000;9234:968-74.

20. Han EC, Ryoo SB, Park BK, Park JW, Lee SY, Oh HK, et al. Surgical outcomes and prognostic factors of emergency surgery for colonic perforation: would fecal contamination increase morbidity and mortality?. International Journal of colorectal disease 2015:1-10.

21. Busić Z, Cupurdija K, Kolovrat M, Servis D, Amić F, Cavka M, et al. Emergency Surgery for Large Bowel Obstruction caused by Cancer. Collegium antropologicum 2014;1:111-4.
22. Gainant A. Emergency management of acute colonic cancer obstruction. J Visc Surg 2012;149:3-10.

23. Papadimitriou G, Manganas D, Phedias Georgiades C, Vougas V, Vardas $\mathrm{K}$, Drakopoulos S. Emergency surgery for obstructing colorectal malignancy: prognostic and risk factors. J BUON 2015;20:406-12.

24. Wong SK, Young PY, Widder S, Khadaroo RG. A descriptive survey study on the effect of age on quality of life following stoma surgery. Ostomy Wound Manage 2013;59:16-23.

25. Gündoğdu RH, Yaşar U, Ersoy PE, Ergül E, Işıkoğlu S, Erhan A. Effects of preoperative nutritional support on colonic anastomotic healing in malnourished rats. Ulus Cerrahi Derg 2015;31:113,7.

26. Formisano V, Di Muria A, Connola G, Cione G, Falco L, De Angelis CP, et al. Our experience in the management of obstructing colorectal cancer. Ann Ital Chir 2014;85:563-8.

27. Ansaloni L, Andersson RE, Bazzoli F, Catena F, Cennamo V, Di Saverio $\mathrm{S}$, et al. Guidelenines in the management of obstructing cancer of the left colon: consensus conference of the world society of emergency surgery (WSES) and peritoneum and surgery $(\mathrm{PnS})$ society. World J Emerg Surg 2010;5:29.

28. Park SY, Chung JS, Kim SH, Kim YW, Ryu H, Kim DH. The safety and prognostic factors for mortality in extremely elderly patients undergoing an emergency operation. Surgery today 2015:1-7.

29. Ng HJ, Yule M, Twoon M, Binnie NR, Aly EH. Current outcomes of emergency large bowel surgery. Ann R Coll Surg Engl 2015;97:151-6.

30. Bouassida M, Charrada H, Chtourou MF, Hamzaoui L, Mighri MM, Sassi S, et al. Surgery for Colorectal Cancer in Elderly Patients: How Could We Improve Early Outcomes? J Clin Diagn Res 2015;9:PC04,8.

31. Raats JW, van Eijsden WA, Crolla RM, Steyerberg EW, van der Laan L. Risk Factors and Outcomes for Postoperative Delirium after Major Surgery in Elderly Patients. PLoS One 2015;10:0136071.

32. Ansaloni L, Catena F, Chattat R, Fortuna D, Franceschi C, Mascitti P, et al. Risk factors and incidence of postoperative delirium in elderly patients after elective and emergency surgery. Br J Surg 2010;97:273-80.

33. Tentes AA, Mirelis CG, Kakoliris S, Korakianitis OS, Bougioukas IG, Tsalkidou EG, et al. Results of surgery for colorectal carcinoma with obstruction. Langenbecks Arch Surg 2009;394:49-53.

34. Cuffy M, Abir F, Audisio RA, Longo WE. Colorectal cancer presenting as surgical emergencies. Surg Oncol 2004;13:149-57.

35. Svenningsen P, Manoharan T, Foss NB, Lauritsen ML, Bay-Nielsen M. Increased mortality in the elderly after emergency abdominal surgery. Dan Med J 2014;61:4876.

36. Bosscher MR, van Leeuwen BL, Hoekstra HJ. Mortality in emergency surgical oncology. Ann Surg Oncol 2015;22:1577-84.

37. Heriot AG, Tekkis PP, Smith JJ, Cohen CR, Montgomery A, Audisio RA, et al. Prediction of postoperative mortality in elderly patients with colorectal cancer. Dis Colon Rectum 2006;49:816-24. 


\section{Doksanlı yaşlardaki hastalarda komplike kolorektal kanser: Acil durumda anastomoz yapmamak daha mi iyi?}

Dr. Belinda De Simone, ${ }^{1}$ Dr. Federico Coccolini, ${ }^{2}$ Dr. Luca Ansaloni, ${ }^{2}$ Dr. Antonio Tarasconi, ${ }^{3}$ Dr. Gianluca Baiocchi, ${ }^{3}$
Dr. Nereo Vettoretto, ${ }^{4}$ Dr. Peggy Joly, ${ }^{5}$ Dr. Marianne Ferron, ${ }^{5}$ Dr. Alessandro Pozzo, ${ }^{5}$ Dr. Lionel Charre, ${ }^{5}$
Dr. Salomone Di Saverio, ${ }^{6}$ Dr. Josephine Andrea Napoli, ${ }^{7}$ Dr. Ferdinando Agresta, ${ }^{8}$ Dr. Massimo Sartelli, ${ }^{9}$ Dr. Fausto Catena ${ }^{1}$ Dr. Salomone Di Saverio, ${ }^{6}$ Dr. Josephine Andrea Nap

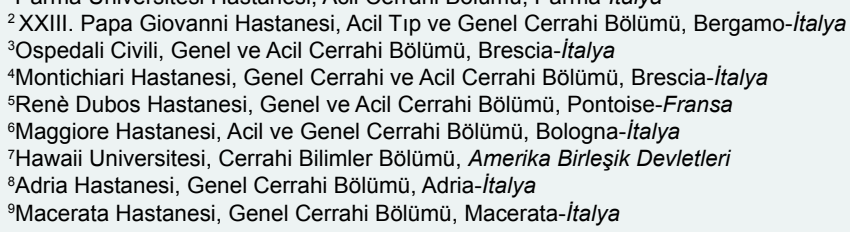

AMAÇ: Kolorektal kanser (KRK) başlıca yaşı kişilerin hastalı̆ıdı. Doksanlı yaşlardaki hastalarda kanser cerrahlar ve onkologlar için etik bir ikilemi temsil eder. Bu hasta grubunda, komplike KRK'nin acil durumda tedavisi tartışımaktadır. Kolorektal kanser komplikasyonları için acilen cerrahiye başvuran doksanlık hastalarda altı acil cerrahi bölümünün tedavideki deneyimlerini sunmak amacıyla bu geriye dönük çalışma yapıldı.

GEREÇ VE YÖNTEM: Ocak 20 I I ile Haziran 2015 arasında komplike KRK için altı acil cerrahi kliniğinde yatırılan 90 yaş üstü hastalara ilişkin veriler geriye dönük olarak analiz edildi. Veriler bu amaca ilişkin veri tabanında toplandı. IBM SPSS 22 yazılımı kullanılarak istatistiksel analiz yapıldı ve istatistiksel anlamlılık düzeyi olarak $p=0.05$ belirlendi.

BULGULAR: Çalışma döneminde 90 yaş üstü 15 hasta komplike KRK için acilen cerrahi geçirdi. Olguların \%52.63'ü kadın olup kadın/erkek oranı I. I I: I ve yaş ortalaması 92.52 I I.49 yıl (dağılım: 90-97) idi. Ameliyat öncesinde ASA skoruyla cerrahi risk değerlendirildi. ASA skorları $\leq 3$ ve $>3$ olan hastalar arasında hastane içi mortalitede istatistiksel açıdan hiçbir farklılık yoktu. Hastaların \%3।.57'sinde (6/I9) primer anastomoz uygulandı. Bu hastaların tümü sağ kolon kanserinden etkilenmişti. Hastaların \%63. I5'ine (12/19) diversiyon stroması gerçekleştirildi. Sağ veya sol kolon kanser hastalar arasında ameliyat sonrası komplikasyonların insidansı arasında istatistiksel açıdan farklıık vardı $(p=0.0498)$. Hastanede ortalama kalı̧ süresi

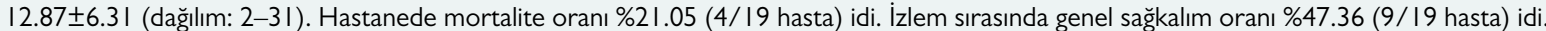

TARTIŞMA: Etkilenmiş hastaların tümünde KRK'yi tedavi etmenin en iyi yöntemi elektif cerrahidir. Hastaların ameliyat öncesinde dikkatli seçimi ve değerlendirmesiyle 90 yaş üstü hastalarda KRK komplikasyonları için acil cerrahi mümkündür. Seçilmiş hastalarda tek evrelik cerrahi en iyi seçimdir. Peritonitli, güçsüz hastalarda, hemodinamik açıdan kararsız, anastomoz yeri kaçağı açısından yüksek risk taşıyan hastalarda iki-üç evreli cerrahi endikedir. Elektif cerrahiye geçiş olarak ve ilerlemiş neoplastik hastalıkta palyatif işlem olarak dekompresif stoma gerçekleştirilir. Acil durumlarda doksanlık hastalarda cerrahi riski, morbidite ve mortaliteyi azaltma açısından diversiyon stoması iyi bir cerrahi seçimdir. Bunu doğrulama için klinik randomize kontrollü çalışmalara gerek vardır.

Anahtar sözcükler: Acil cerrahi; dekompresif stoma; doksanlık hasta; kalın bağırsak tıkanıklığı; kolorektal kanser; primer anastomoz.

Ulus Travma Acil Cerrahi Derg 2017;23(I):15-22 doi: 10.5505/tjtes.2016.77I78 